\title{
КРИМІНАЛЬНА ДЕЛІНКВЕНТНІСТЬ ЯК ОБ'СКТ ГУМАНІТАРНИХ НАУК
}

\author{
СЛИНЬКО Сергій Вікторович - доктор юридичних наук, професор \\ Харківського національного університету внутрішніх справ \\ orcid.org/0000-0002-2182-1436 \\ СЛИНЬКО Дмитро Сергійович - доктор юридичних наук, доцент \\ Харківського національного університету ім. В.Н. Каразіна \\ ФИЛИН Дмитро Вітальович - кандидат юридичних наук, доцент \\ Національного юридичного університету ім. Я. Мудрого \\ СТРАТОНОВ Василь Миколайович - доктор юридичних наук, професор \\ Херсонського державного університету \\ УДК 341.131 \\ DOI 10.32782/NP.2020.4.8
}

\begin{abstract}
Законодательство Украинъ постоянно совершенствуется. На основе проведения уголовно-правовой ребормы теоретические и практические изменения уголовного, административного, процессуального законодательства бъло введено новые положения, которье должнь соединить конструкиию общей и специальной теории уголовного права и процесса в единое научное обозначение и дать теоретическое определение новъм положениям диспозиции норм права. Только теория имеет возможность раскрылть не только правовое содержание норм права, а также оказать практическое содействие по использованию законодательной базы органами уголовной юстииии в ее точном, неуклонном, объективном выполнении. Теоретические конструкици уголовного, административного права и прочесса имеют существеннве противоречия в определении отдельньх юридических терминологий, которье в нормах материального права определяются как преступление. Нормы уголовного прочесса указъгают на совершение уголовного правонарушения, однако не предоставляют теоретического обоснования данной категории. Административное право дает понятие проступка, но законодательством данное определение введено в уголовное право и прочесс. Досудебное производство проводится в форме досудебного расследования, где следователь, прокурор должнъи установить бакт совершения уголовного правонарушения. Вторая борма досудебного производства указвивает, ито при производстве дознания устанавливается виновное
\end{abstract}

лицо, совершившее уголовньй проступок. Наука поставила новъе задачи по теоретическому определению уголовного преступления u проступка. На основании общих положений уголовного, административного права и процесса обосновъвается существование новой теоретической конструкиии уголовной делинквентности, которая объединяет юридические формъ преступления, уголовного правонарушения и проступка. Раскрьиваются теоретические подходъ к определению делинквентности. Вносится предложение по установлению единой терминологии, обосновъиваются данная категория, которая включает в себя не только личность правонарушителя, а указылает на сочиальньле условия совершения уголовного преступления, правонарушения, проступка.

Ключевые слова: право, фбилософбия, сочиология, закон, делинквентность, преступление, уголовное правонарушение, проступок, органъг уголовной юстищии.

\section{Актуальність статті}

Зміни чинного законодавства України встановили нові положення, які повинні поєднати конструкцію загальної та спеціальної теорії кримінального права та процесу у едине термінологічне визначення, надати елементи диспозиції статі, що розкривають не тільки правовий зміст, а також практичне значення для користування органів кримінальної юстиції. Загальні теорії кримінального права та процесу мають суттєві протиріччя у визначенні юридичної термінології, які в 


\section{Кримінальне право, кримінальний процес та криміналістика}

нормах матеріального права визначаються як злочин. Норми кримінального процесу вказують на кримінальне правопорушення, однак не надають теоретичного обгрунтування цієі категорії. Адміністративне право надає поняття проступку. Цю категорію введено до кримінального права та процесу.

Кримінальний процес України встановив, що досудове провадження проводиться у формі досудового розслідування та дізнання. Досудове розслідування повинно встановити обставини вчинення кримінального правопорушення та визначати вину підозрюваного.У цьому разі закон визначає як синоніми кримінальний злочин та правопорушення.

Досудове розслідування у формі дізнання здійснює дізнавач. Він повинен встановити обставини кримінального проступку. Теоретичні положення кримінального права та процесу визначають, що проступок є не тяжкий злочин.

Адміністративне право визначає проступок як протиправну дію або бездіяльність, що порушує встановлений законом правовий порядок. Кримінальний процес не надає визначення кримінального проступку та його протиріччя з адміністративним правом.

Перед наукою практика поставила завдання щодо визначення, розмежування та місця кримінального злочину, правопорушення та проступку і не лише в кримінальному праві.

Мета статті полягає у визначенні поняття соціального явища як кримінальна делінквентність. Виходячи з комплексного підходу до цієї проблеми, на основі застосування окремих положень психології, соціології, кримінології, кримінального права і процесу, криміналістики дається аналіз причин і умов існування кримінальної делінквентністі як соціальноюридичного феномену. Окреслені перспективи вдосконалення окремих напрямків науки i практики для усунення та попередження протиправних явищ. На підставі загальних положень кримінального, адміністративного права та процесу надається нова теоретична конструкція кримінального злочину, правопорушення, проступку у єдиній термінології. На підставі теоретичного обгрунтування структурних елементів кримінальної делінквентністі визначається їі сутність, що поєднує юридичні феномени злочину, кримінального правопорушення та кримінального проступку. Визначити теоретичні і практичні елементи кримінальної делінквентності, які надають основні аспекти боротьби зі злочинністю у державі, допомагають забезпечити правопорядок у суспільстві, надають підстави захисту особи від кримінальних проявів.

Новизна статті складається 3 теоретичних положень фундаментальних наук, перш за все, кримінального циклу, які використовуються для розкриття суті кримінальної делінквентністі. Взято до уваги, загальний напрямок філософської думки, соціології, психології, логіки та окремих аспектів кримінально правових положень щодо скорочення зростання кримінальної делінквентністі в суспільстві. Визначаються перспективи правових напрямків діяльності держави щодо запобігання кримінальних правопорушень. На підставі чинного кримінального, адміністративного, процесуального законодавства, яке має за мету боротьбу з кримінальними деліктами визначається, що держава, іiі правоохоронні органи, суспільство повинні забезпечити захист особи, охорону прав, свобод та законних інтересів усіх учасників кримінального провадження, щодо яких було вчинено кримінальний злочин, кримінальне правопорушення, кримінальний проступок. Пропонується поєднати важливі структурні елементи кримінально-протиправного явища у єдине правове визначення, яку встановити у формі делінквентністі.

Теоретичне обгрунтвання загальних положень статті можна визначити на підставі наукових підходів, які встановлені в кримінальному праві та процесі, адміністративному праві та процесі.

Не можна перерахувати всіх авторів у галузі кримінального права які надали теоретичне обгрунтвання кримінального злочину. Ю.В. Баулін, М.О. Панов, В.Я. Тацій та ін. розкрили зміст злочину, надали його структуру та запропонували його теоретичну структуру. Ці наукові публікації є основою для застосування норм кримінального права. 
Ю.П. Аленін, Ю.М. Грошевой, М.М. Міхеєнко та інші автори в галузі кримінального процесу розкрили процесуальні положення розслідування кримінального злочину, надали елементи кримінального правопорушення та обставин, що вказують на вину підозрюваного у його вчиненні.

Ю.П. Битяк, В.Я. Настюк, С.В. Ківалов та ін. розкрили зміст проступку та надали його структурні, правові елементи, а також визначили адміністративну відповідальність за їх вчинення.

Правова наука, окремі іiі галузі вивчають та розкривають поняття, класифікацію, види злочинів і кримінальних проступків. Науковий підхід дозволив розширити визначення цих категорій як протиправного, соціально небезпечного явища.

Автори наукових публікацій та їх опоненти мають єдиний теоретичний підхід до основних соціальних завдань, що стоять перед суспільством. Вони вважають, що необхідно обмежити кримінальну делінквентність, скоротити іï не тільки в кількісному визначені, а також у якісному аспекті. Теоретичні положення визначать межі кримінальної делінквентністі на підставі політичних, економічних, соціальних процесів, що встановлені у суспільстві. Ретроспективний аналіз генезу, рівня кримінальних прояв, а також засоби, що встановлені для обмежування протиправного впливу щодо осіб постійно знаходиться в центрі уваги гуманітарних наук. Теоретичні конструкції кримінальної делінквентністі є об'єктом пізнання не тільки юридичних наук, а сьогодні до боротьби з протиправними явищами приєдналися філософія, логіка, психологія та низка інших гуманітарних наук. Кожне положення її сторони досліджується правовими та гуманітарними науками та виступає як предмет, об'єкт дослідження. Теоретичні положення сформульовані на підставі точок зору вчених, які вказували на складність і багатогранність проблем злочинності, яка впливає на економічну, соціальну, кримінальну, кримінологічну політику держави та суспільства. Позиції, які висловлені у літературі, дозволяють створити надійний фундамент для подальшого, більш ретельного дослідження такої проблеми, як кримінальна делінквентність.
Виклад загального матеріалу можна розпочати на підставі визначення вчених, які звертали увагу на складність протиправної дії або бездіяльності під час вчинення кримінального злочину.

Б.М. Кедров один з перших писав: «Може здатися, що проблема злочинності суто юридична. Тим часом для свого вивчення вона вимагає участі не тільки правової науки, а й цілого ряду інших суспільних наук, починаючи з економічних і закінчуючи філософськими, в тому числі наукою про мораль. Чимале значення мають тут вивчення сімейних відносин, постановки справи виховання, загальної освіти, питання використання вільного часу тощо » $[1$, с.25].

Аналіз цього висловлювання надає підстави для висновку, зокрема кримінальна делінквентність не охоплює повністю об'єкт гуманітарних наук, але $є$ його частиною. Об'єкт гуманітарних наук $€$ життя, економічні, соціальні, побутові умови суспільства. Учені матеріального права вказують, що однією зі сторін суспільства $є$ злочинність. Ця теоретична, матеріальна проблема присутню у всіх галузях наук, тим паче у гуманітарних дослідженнях. При цьому необхідно зазначити, що правові процеси у суспільстві можуть мати значення в різних правових відносинах. Кожна сторона суспільства може включатися в предмет окремої гуманітарної науки.

Послідовно переходячи від абстрактного до конкретного, від гуманітарних наук до прикладних, можна встановити ієрархію наук, предметом яких $є$ злочинність.

Перший рівень складають філософські науки, а саме філософія, філософія права, соціологія, етика, соціальна психологія та ін. Другий рівень можна визначити на підставі юридичних наук. Основою юридичних наук є теорія держави і права. Далі можна запропонувати юридичну (правову) соціологію, антропологію, кримінологію, кримінальне право, процес, криміналістику. На першому рівні кримінальна делінквентність встановлена 3 позиції властивості людини. У такому випадку проблема кримінальної делінквентністі для філософії - це проблема правової поведінки, а саме соціальної.

Э.А. Поздняков визнав злочинність негативним явищем людини. Філософія не запе- 


\section{Кримінальне право, кримінальний процес та криміналістика}

речує і не схвалює іï, а вивчає як об'єктивну реальність [2, с.230].

Новий імпульс розвитку отримала філософія права. 3 одного боку, наука намагається підняти деякі юридичні проблеми до рівня філософського визначення, 3 іншого, надає спробу філософствування в юридичних термінах 3 метою отримання високого ступеня абстрактності у юридичних науках. Якщо предметом філософії є об'єктивна реальність, то філософія права займається дослідженням змісту права, його сутності. Тим часом органічну єдність предмета філософії права не виключає відмінності в підходах до філософських проблем права.

B.C. Нерсесянц розглядає сутність права, його поняття, правову онтологію, правову аксіологію, правову гносеологію з точки зору філософських проблем права [3, с.27].

С.С. Алексеєв, Ю.В. Тіхонравов акцентували увагу на логічному та історичному аспекті права, позитивному і природному [4; 5].

Аналіз їх наукових публікацій надає підстави для визначення, що вчені, які займаються філософією права, не приділили належної уваги філософським аспектам кримінальної делінквентністі.

В.А. Бачінін одним з перших у філософії права розкрив проблеми злочинності. Він зазначав, що мнемотичний (від імені грецької богині Мнемозіни) простір деструктивного кримінального досвіду існуе реально. Більше того, під час історичного розвитку це поняття було розширено. Подібно до того, як разом 3 навичками виготовлення отрут вчені отримують навички виготовлення ліків протиотрут, так людський дух не тільки знаходить кримінальний досвід, а й виробляе досвід 3 подолання, нейтралізації, знешкодження деструктивного потенціалу. Злочин є матеріалом для пізнання, вивчення людської природи, його психологічних, соціологічних, філософських та інших елементів. Будучи винятковою, екстремальною, «пороговою» ситуацією, злочин має властивість відчувати людину, змушує його проявитися і розкритися повністю, виявити ті якості, які за інших обставин залишалися б прихованими [6, с.444-445].

С.В. Бородин, Д.А. Керімов, В.Н. Кудрявцев, Ю.В. Кудрявцев, В.С. Нерсесянц та ін. вказували, що предметом філософії злочину є не особа злочинця, не соціальні, природні причини злочину, а першопричини [7, с.448; 8, c.131].

N. Smelzer вказував, що для соціології злочин $є$ наслідком нездатності соціальних суб'єктів знайти цивілізовані форми вирішення протиріччя. Якщо для філософії злочин 6 однією формою суспільного життя, то для соціології злочин - це соціально неправова поведінка. Він надав розгорнутий аналіз щодо того, як поведінка окремої категорії соціальних суб'єктів відхиляється від загальної поведінки, що встановлена суспільством. Ці положення визначені як девіантність. У житті соціальні очікування носять цілком стабільний характер, хоча змінюються протягом часу під впливом економічних, політичних та інших чинників. Найбільш істотним відхиленням від соціальних очікувань (норм) є злочин (делікт) [9, с.194].

N. Kristi вказував, що соціологічному визначенню злочинності (сучасної кримінальної делінквентністі) відповідають соціальні засоби впливу на неї. Засобами соціального впливу є формальний і неформальний соціальний контроль. Неформальний соціальний контроль здійснюе суспільство. Формальний контроль забезпечується державними органами. 3 точки зору соціологічного підходу, як до формального, так і неформального контролю є неможливість в повній мірі оцінити і виміряти реально існуючий негативний вплив на делінквентну поведінку суб'єкта. Ослаблення правоохоронних органів, з одного боку, а 3 іншого, безкарність злочинних угруповань створило криміналізовану субкультуру [10, с. $142-171]$.

Майерс Д., досліджуючи проблему співвідношення добра і зла, констатував, що вони поєднані в цій якості кожного. Ні добро, ні зло не знаходять обгрунтування і виправдання. Суб'єкт здійснює добрі або злі вчинки, виходячи не тільки з миттєвої ситуації, а також 3 власного розуміння добра і зла. Теоретичні положення соціальної психології дозволяють усунути фактори, що впливають на формування кримінальних установок, запобігати кримінальним правопорушенням. Сутність фундаментальної помилки атрибуції $є$ в тому, що вчинення кримінального правопорушення слідчий приписує негативним рисам підозрю- 
ваного, обвинуваченого. Однак, підозрюваний, обвинувачений, як правило, посилається на несприятливі зовнішні фактори вчинення кримінального правопорушення (злочину) [11, c. 31].

Методами соціальної психології можна назвати низку заходів, спрямованих на оздоровлення суспільної свідомості, попередження кримінальних деліктів, вдосконалення способів виявлення, розкриття, розслідування, судового розгляду кримінальних проступків, а також підвищення ефективності виконання кримінального покарання.

Друга конструкція кримінальної делинквентності включає в себе юридичні науки, які поділяються фундаментальні та прикладні.

Б.М. Кедров визначав, що класифікація системи наук будується на основі відповідей на три питання: що пізнається? як пізнається? для чого пізнається? Науки, які відповідають на перші два питання; належать до фундаментальних. Науки, що відповідають на трете питання: «для чого пізнається?», належать, як правило, до прикладних [12, с. 50 - 52].

B.C. Нерсесянц звертав увагу не тільки на єдність і взаємозв'язок держави та права, а також на різну порядкову їх природу. Він вважає, що саме понятійна правове розуміння і визначення відповідного кола емпіричних явищ (об’єктів) як діюче право є результатами пізнавальних, системно утворюючих та структурно утворюючих функцій юридичного методу, за допомогою якого здійснюються конкретизація і перетворення загального поняття права стосовно пізнання особливостей цих об’єктів. Звідси предмет загальної теорії права і держави - це формулювання, розробка і конкретизація єдиного загального поняття права і держави як предмета і методу системи юридичних наук. Предметом загальної теорії права та держави є формулювання, розробка та конкретизація єдиного загального поняття права і держави, як предмета і методу системи юридичних наук [3, с.73].

Необхідно зазначити, що теоретичні положення держави і права не визначають проблеми кримінальної делінквентністі. Ці конструкції зачіпають окремі ії елементи та надають характеристику заборонених норм права, санкцій, аспектів юридичної відповідальності. Дослідження окремих елементів криміналь- ної делінквентністі не можуть задовольнити потреби прикладних юридичних наук, мета яких включає до себе розробку засобів і методів обмеження кримінальних проступків. Поряд з розподілом усіх юридичних наук на фундаментальні та прикладні, доцільно виділяти науки, окремих, відносно автономних, циклів. До цих наук слід віднести науки предметом яких є суспільні відносини, що виникають, змінюються і припиняються в певній сфері суспільства. Такий підхід дозволяє виділити науки конституційного, кримінального, цивільного та інших циклів.

До наук кримінального циклу, що безпосередньо займаються проблемами кримінальної делінквентністі та впливу на неї, відносяться кримінологія, кримінальне право, кримінальний процес, кримінально-виконавче право та криміналістика. Необхідно вказати, що значна роль у науках кримінального циклу належить кримінології. Вона $є$ комплексною наукою про закономірності кримінальної делінквентності у їі конкретних проявах, викриває особливості цього соціального юридичного явища, вказує на фактори, причини, умови, що породжують та обумовлюють кримінальну делінквентність. Ї̈̈ призначення полягає в аналізі окремої категорії кримінальних правопорушень, злочинів, кримінальних проступків, а також визначенні форм, методів, методики нормативного та соціального впливу з метою контролю за визначеними негативними явищами

На підставі розподілу юридичних наук на фундаментальні і прикладні доцільно виділити окремі галузі автономних циклів. До кримінального циклу, на підставі якого розкриваються проблеми кримінальної делінквентності, відносяться кримінальне право та процес, криміналістика, кримінологія та ін. Кримінологія $є$ наукою про закономірності кримінальної делінквентності у конкретних проявах, причинах та умовах, що породжують кримінальну делінквентність.

I.M. Даньшин визначив серцевину предмета кримінології, а саме: кримінальну делінквентність; кримінальні правопорушення; особу, яка вчинила злочин; фактори, які впливають на кримінальну делінквентність; аспекти попередження кримінальної делінквентністі та їі проявів. До числа головних 


\section{Кримінальне право, кримінальний процес та криміналістика}

проблем, що утворюють серцевину предмета кримінології, відносяться. По-перше, кримінальна делінквентність. По-друге, окремі види кримінальних правопорушень, злочинів, кримінальних проступків, як конкретні прояви. По-третє, фактори, які впливають на кримінальну делінквентність, підстави для ïх можливого попередження та визначення окремих її проявів. Особливу увагу приділяється визначення обставин вчинення кримінального злочину особою, яка мала підстави для його вчинення. Визначаються всі обставини, які впливають на тяжкість вчинення кримінального злочину, соціальні, психологічні, моральні та інші структурні елементи. Усе викладене вказує, що кримінологія є базовою наукою для наук кримінального права, процесу, криміналістики, кримінально-виконавчого права. Взаємозв'язок кримінології з іншими науками кримінального циклу різноманітний. Кримінальному праву вона надає відомості про рівень кримінальної делінквентності, що дозволяє судити про сукупну суспільну небезпеку тих чи інших кримінальних проступків. На підставі цих даних визначається необхідність криміналізації або декриміналізації суспільно небезпечних діянь [15, с. 10].

Результати кримінологічних досліджень надають умови для законодавця щодо диференціації кримінальної процесуальної форми досудового розслідування та судового розгляду злочину, кримінальних правопорушень, та кримінальних проступків.

Зазначимо, що між окремими науками кримінального циклу існує взаємозв'язок i взаємодія. Протягом років було прийнято вважати, що кримінальне матеріальне право є основою і правовим фундаментом кримінального процесуального права. Прихильники цієї концепції виходили з того, що саме кримінальним законодавством встановлюються діяння, визнані державою та суспільством кримінальними деліктами. Кримінальне процесуальне право було покликане забезпечити об'єктивне, всебічне і повне встановлення обставин вчинення кримінального правопорушення, осіб, які його вчинили, а також гарантувати законність, неупередженість, обгрунтованого, об'єктивного, справедливого судового рішення. Тільки суддя має процесуальні повноваження щодо постанови вироку, за яким визнає обвинуваченого засудженим та встановлює всі обставини кримінального правопорушення.

Однак, як було підкреслено фахівцями в галузі методології, завдання формулюється тільки тоді, коли вже є у наявності засоби їх вирішення. Таким чином, кримінальне процесуальне право прямо і безпосередньо не залежить від кримінального права. На формування цих двох галузей права істотно впливає кримінологія. Зі сказаного можна зробити висновок, що кримінологія є базовою, фундаментальною науку кримінального циклу.

На характер і якість засобів обмеження кримінальної делінквентністі істотно впливають консолідуючі наукові теорії, тобто теорії, що формуються в зонах перетину предметів двох і більше наук, але вони самі не є науками. До таких теорій відносяться юридична психологія, юридична конфліктологія, загальна теорія прав людини, теорія доказів і деякі інші. Ці теорії, у період свого становлення, були визначені як «територія» конкурентної боротьби декількох наук.

Наприклад, теорія доказів була предметом дослідження з боку кримінального процесу та криміналістики. Вчені постійно вели наукові дебати щодо належності цих теоретичних положень до предмету тільки «своєї» науки. У міру визначення єдиної термінології наукового предмета вчені прийшли до порозуміння необхідності спільної розробки теоретичних положень галузевих наук. Під час міждисциплінарних наукових дискусій окремі теорії права, процесу, криміналістики набувають інтегративної сутності та об’єднуються у єдиний комплекс.

у міру більш поглибленого наукового осмислення предмета згаданих теорій приходить розуміння необхідності спільної їх розробки представниками конкуруючих спочатку наук. У ході міждисциплінарних наукових досліджень ці теорії набувають інтегративну сутність і об'єднують науки автономного циклу в єдиний комплекс.

Визначення предмета кожної юридичної науки кримінального циклу дозволяє сформувати досить повне розуміння кримінальної делінквентністі як специфічної людської діяльності та атрибуту суспільства. Зміст, якість засобів обмеження кримінальної делінквент- 
ності істотно впливає на консолідуючі наукові теорії, на такі, що формуються в зонах перехрестя предметів двох або більшої кількості наук, але вони самі не є науками. До таких теорій відносяться юридична психологія, конфліктологія, загальна теорія прав людини та ін. Теоретичний підхід до визначення цих наукових положень, у період свого становлення, є «територією» конкурентної боротьби декількох наук.

Висновок. Кримінальна делінквентність 6 єдиним об'єктом наук кримінального циклу, предметом кожної 3 яких $\varepsilon$ окрема сторона цього феномена. Найбільш перспективними представляються міждисциплінарні дослідження 3 метою формулювання інтеграційних (консолідуючих) теорій, що дозволяють не тільки зрозуміти і пояснити кримінальну делінквентність як атрибут соціального життя, а визначити шляхи найбільш ефективного впливу на неї з метою обмеження і скорочення до соціально прийнятних меж.

\section{Мiтература}

1. Кедров Б.М. Классификация наук. Книга 3. Прогноз К. Маркса о науке будущего. М. 1985. - 520с.

2. Поздняков Э.А. Философия преступления.- М. 2001. - 576с.

3. Нерсесянц В .С. Философия права. М. Норма. 1997. - 848c.

4. Тихонравов Ю.В. Основы философии права. - М. Вестник. 1996. - 608с.

5. Алексеев С.С. Философия права. История и современность. Проблемы. Тенденции. Перспективы. - М. Норма. 1998. - 608с.

6. Бачинин В.А. Философия права и преступления. - Харьков, Фолио. 1999. - 607с.

7. Бородин С.В., В.Н. Кудрявцев, Ю.В. Кудрявцев, В.С. Нерсесянц Социальные отклонения. - М.: Юрид. Аит. 1989. - 368 с.

8. Керимов Д.А. Методология права (предмет, функции, проблемы философии права): монография. - М. Аванта. 2001. $560 \mathrm{c.}$

9. Смелзер Н. Социология. - М. Феникс. 1998. - 688c.

10. Нильс Кристи. Удобное количество преступлений.- СПб. Алетея. 2006. - 184 с.
11. Майерс Д. Социальная психология. - СПб. 2002. -1325с. [электронный ресурс]: режим доступа: http://vdushe.narod.ru/D. Majers_part1_.pdf

12. Кедров Б.М. Соотношение фундаментальных и прикладных наук. Вопросъ филособбии. 1971. № 9. - С. 50 - 52.

13. Алешина И.А., Наумова С.Ю., Мордовца А.С., Касаевой Т.В.. Общая теория государства и права: учебник.- Саратов. 2018. 392 с. [электронный ресурс]: режим доступа: http://www.seun.ru/content/learning/4/science/1/ doc/Naumov_Obsha_teorgos_2018.pdf

14. Матузов Н.И., Малько А.В. Теория государства и права: учебник. Саратов. Юристь. 2004. - 245с. [электронный ресурс]: режим доступа: http://pravo-olymp.ru/wpcontent/uploads/2013/04/TGP_Matuzov_Malko. pdf

15. Даньшин И.Н. Введение в криминологическую науку. - Харьков. 1998. - 144c.

16. Дворкин Р. Империя права. - М. 2020. - 592 с.

17. Белов В.А. Ценностное измерение науки. М.: Идея-пресс, 2001. - 279с.

\section{Literature}

1. 1. Kedrov B.M. Classification of Sciences. Book 3. K. Marx's forecast about the science of the future. M. 1985 .-- 520s.

2. Pozdnyakov E.A. Philosophy of crime. - M. 2001. - 576s.

3. Nersesyants V.S. Philosophy of Law. - M. Norma. 1997 .-- 848s.

4. Tikhonravov Yu.V. Foundations of the philosophy of law. - M. Bulletin. 1996 .-- 608s.

5. Alekseev S.S. Philosophy of Law. History and modernity. Problems. Trends. Perspectives. M. Norma. 1998 .-- 608s.

6. Bachinin V.A. Philosophy of law and crime. - Kharkiv, Folio. 1999 .-- 607s.

7. Borodin S.V., V.N. Kudryavtsev, Yu.V. Kudryavtsev, V.S. Nersesyants Social deviations. -M .: Jurid. Lit. 1989 .-- 368 s.

8. Kerimov D.A. Methodology of law (subject, functions, problems of philosophy of law): monograph. - M. Avanta. 2001 .-- 560 p.

9. Smelzer N. Sociology. - M. Phoenix. 1998 $--688 s$.

10. Nils Christie. Convenient number of crimes. - St. Petersburg. Alethea. 2006 .-- 184 p. 


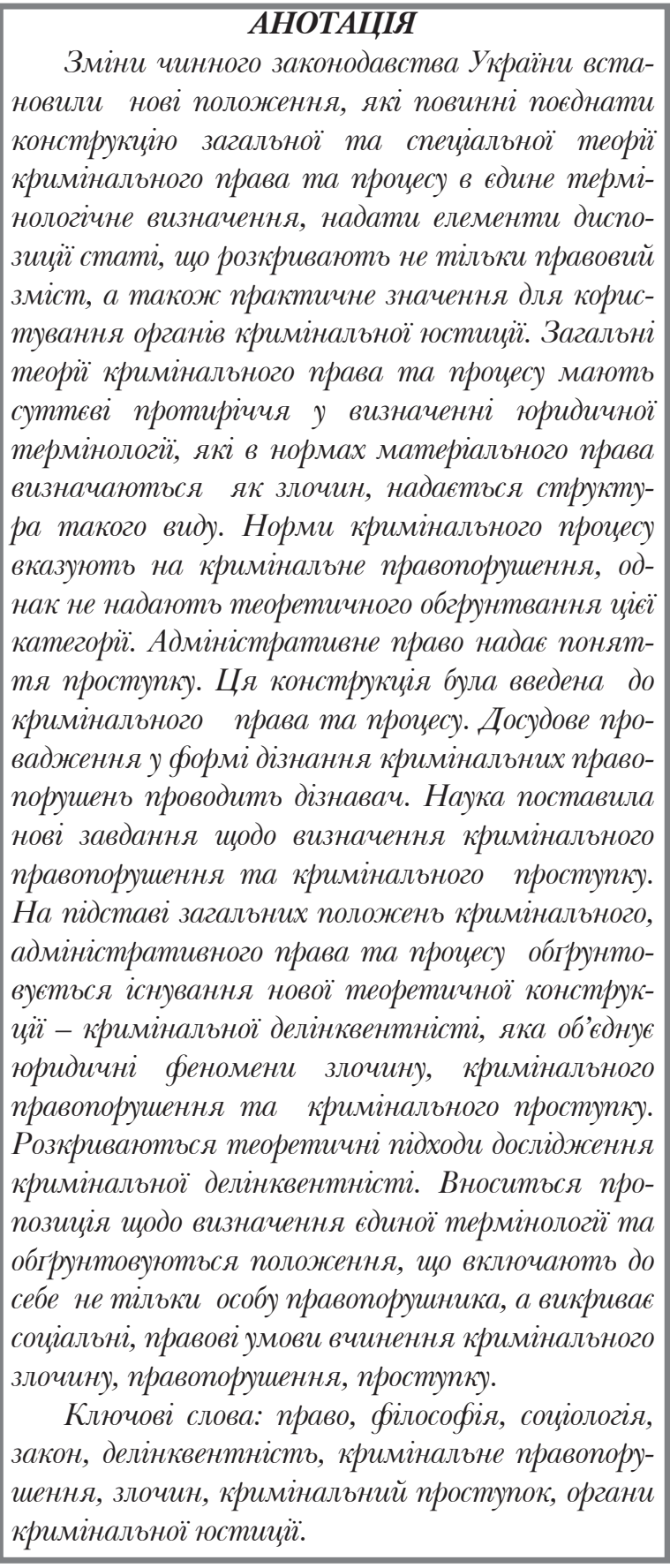

11. Myers D. Social psychology. - SPb. 2002.1325s. [electronic resource]: access mode: http:// vdushe.narod.ru/D._Majers_part1_.pdf

12. Kedrov B.M. The ratio of fundamental and applied sciences. Philosophy questions. 1971. No 9. - P. 50 - 52.

13. Aleshina I.A., Naumova S.Yu., Mordovets A.S., Kasaeva T.V .. General theory of state and law: textbook.- Saratov. 2018 .-- 392 p. [electronic resource]: access mode: http://www.seun.ru/con-

\section{SUMMARY}

Amendments to the current legislation of Ukraine have established new provisions that should combine the construction of general and special theory of criminal law and process into a single terminological definition, provide elements of gender disposition that should reveal not only legal content, but also provide practical significance for criminal justice. General theories of criminal law and process have significant contradictions in the definition of legal terminology, which in substantive law are defined as a crime, given the structure of this type. The rules of criminal procedure indicate a criminal offense, but do not provide a theoretical justification for this category. Administrative law introduces the concept of offense and introduces it into criminal law and procedure. A pre-trial investigation in the form of an inquiry into criminal offenses must be conducted by an investigator. Science has set new tasks for determining criminal offenses and criminal offenses. Based on the general provisions of criminal, administrative law and process, the existence of a new theoretical construction is substantiated - criminal delinquency, which combines non-legal phenomena of crime, criminal offense and criminal offense. Theoretical approaches to the study of criminal delinquency are revealed. A proposal is made to define a single terminology and the provisions of this category are substantiated, which includes not only the identity of the offender, but also exposes the social conditions of committing a criminal offense, offense, misdemeanor.

Key words: law, philosophy, sociology, law, delinquency, criminal offense, crime, criminal offense, criminal justice bodies.

tent/learning/4/science/1/doc/Naumov_Obsha_ teorgos_2018.pdf

14. Matuzov N.I., Malko A.V. Theory of state and law: textbook. Saratov. Lawyer. 2004 .-- 245s. [electronic resource]: access mode: http://pravoolymp.ru/wp-content/uploads/2013/04/TGP_Matuzov_Malko.pdf

15. Danshin I.N. Introduction to Criminological Science. - Kharkiv. 1998 .-- 144s.

16. Dvorkin R. Empire of Law. - M. 2020 --$592 \mathrm{p}$.

17. Belov V.A. The value dimension of science. M .: Idea-press, 2001 .-- 279s. 